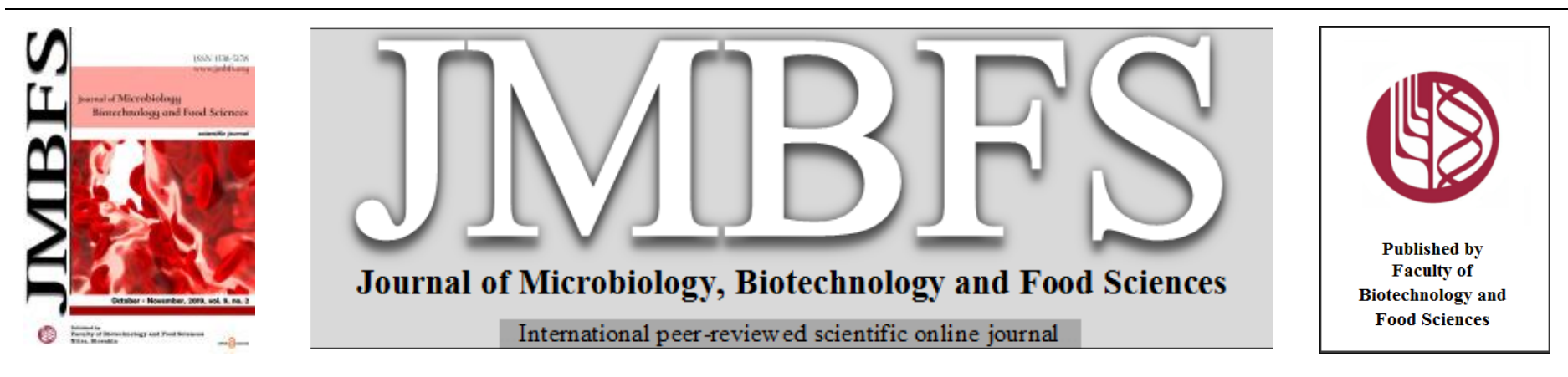

\title{
USE OF COMPOSITE AGRO-SUBSTRATES FOR AMYLOGLUCOSIDASE SYNTHESIS AND CHARACTERIZATION BY Aspergillus niger OTF AND Aspergillus flavus CLOR1 USING SOLID STATE FERMENTATION
}

\author{
Michael B. Osho* and ThankGod Solomon \\ Address(es): Dr. Michael Bamitale Osho, \\ ${ }^{1}$ McPherson University, College of Natural and Applied Sciences (Microbiology Unit), Department of Biological Sciences, Seriki Sotayo, P.M.B 2094, Abeokuta, \\ Ogun State, Nigeria. +2348032698955; +2347083887538; +2347059510010.
}

*Corresponding author: osho_michael@rocketmail.com

doi: $10.15414 / j m b f s .2020 .9 .5 .879-883$

\section{ARTICLE INFO}

Received 29. 9. 2018

Revised 27. 9.2019

Accepted 17. 10. 2019

Published 1. 4. 2020

Regular article

OPEN $\partial_{\text {AcCESS }}$

\begin{abstract}
Amyloglucosidase catalyses the hydrolysisof glycosidic residues from non-reducing ends of amylose and amylopectin in starch components to produce $\beta$-D-glucose for industrial processes. The utilization of composite agro-substrates for amyloglucosidase production byAspergillus niger OTF and A. flavus CLOR1 using solid state fermentation and characterization of the enzyme were investigated. The substrates include rice bran (R), soybeans flour (S), palm kernel cake (P), wheat bran (W) and oyster shell $(\mathrm{O})$ at various compositions (Medium I - VIII) were supplied with adequate moisture content for a solid culture medium of fermentation. They were inoculated into with the isolates and incubated at $30{ }^{\circ} \mathrm{C}$ for $120 \mathrm{~h}$ respectively. Cultural conditions such as temperature, $\mathrm{pH}$ and storage stability were optimized. Medium I (WSPO; 100:2:3:1, w/w) yielded amyloglucosidase activity $83.92 \mathrm{Ug}^{-1}$ and Medium V (WSP; 100:2:3, w/w) resulted into activity $67.64 \mathrm{Ug}^{-1}$ at $48 \mathrm{~h}$ optimal time. There was decline in activity after $48 \mathrm{~h}$ in all samples but with maximum activity at $\mathrm{pH}$ 5. Aspergillus niger OTF showed maximum amyloglucosidase activity23.5 $\mathrm{Ug}^{-1}$ as compared with $A$. flavus CLOR1 $20.07 \mathrm{Ug}^{-1}$ at $30{ }^{\circ} \mathrm{C}$. The residual activities in term of storage stability were $43.9 \%$ and $44.9 \%$ at $4{ }^{\circ} \mathrm{C}$ and $68.6 \%$ and $27.8 \%$ at $28{ }^{\circ} \mathrm{C}$ at week 2 respectively which later declined over a period of time. This study revealed that higher glucoamylase activity was significantly enhanced using these inexpensive and readily available agro-residues by both strains of isolates in solid culture medium. Thus, these residues could be a potential and economic source for the production of amyloglucosidase.
\end{abstract}

Keywords: Amyloglucosidase, Agro-substrates; Aspergillus niger OTF; Aspergillus flavus CLOR1; Solid Culture Medium

\section{INTRODUCTION}

Amyloglucosidase or glucoamylase (GA) is an induction enzyme used in food processing industries as well as in commercial purposes for production of glucose from the non-reducing ends of starch. Apart from amylose and amylopectin fractions of starch, other molecules such as maltose, dextrins and glycogen are hydrolyzed by the enzyme, which also acts on the $\alpha-1,3$ bond (Kumar et al., 2013). A production has been increasingly applied by the process of solid state fermentation (SSF). This cultivation technique is simple with low energy requirements, superior productivity, cost effective fermentation media, without rigorous fermentation control parameters, produces less wastewater, requires simpler equipment, avoids foaming and lowers the risks of contamination (Finore $\boldsymbol{e t}$ al., 2014). Starchy food crops have been reportedly used as substrate for the production of amyloglucosidase, which in turn might leads to shortage of food for human consumption (Anto, 2006). However, several authors have exploited the abundance and availability of agricultural residues by microbial means for the synthesis of amyloglucosidase (Vasudeo, 2010; Lakshmi and Jyothi, 2014; Aliyah et al., 2017). The conversion of these into economic value biocatalyst might greatly reduce environmental and health hazards.

The amyloglucosidasehas been reportedly produced from wheat bran, paddy husk, rice bran, wheat flour, corn flour, coconut seed flour, coconut oil cake, tea waste and other starch containing wastes (Wannapeera and Suneerat 2008; Khan and Sachin, 2011; Kumar et al., 2013; Aliyah et al., 2016). Aspergillus niger has been investigated to possess the potential to utilize agricultural wastes such as rice bran for glucoamylase production using solid state fermentation (SSF) as SSF gains recognition over submerged fermentation $(\mathrm{SmF})$ in term of high rate of productivity, less effluent generation and relatively higher concentration of products (Sarojini et al., 2012).

The principal application of amyloglucosidase is in the production of glucose, a feedstock for the production of high fructose syrups and ethanol for fermentation industries, baking, and brewing and starch processing (James and Lee, 1996; Anto, 2006; Kumar et al., 2013). The present work focused on the production, and characterization of amyloglucosidase at different temperatures, $\mathrm{pH}$ and substrate composition as well as the thermostability and storage methods through solid state fermentation by Aspergillus niger OTF and A. flavus CLOR1 using readily available and abundance agro residues as cheap source.

\section{MATERIALS}

\section{Substrates}

Rice bran, Soya bean flour, Corn bran, Palm kernel cake, Oyster shell were purchased from Livestock Feeds Mill, Abeokuta North Local Government Area, Ogun State, Nigeria.

\section{METHODS}

\section{Sample Collection}

Soil sample was obtained from an Orchard Garden in McPherson University Campus. They were collected in sterile polythene plastic bags and labeled appropriately. These samples were properly mixed together to make a composite samples which were used for the study.

\section{Isolation of microorganisms}

Serial dilution was carried out by dissolving $1 \mathrm{~g}$ of soil sample in $10 \mathrm{ml}$ sterile distilled water. One $\mathrm{ml}$ each of these diluted samples was cultured by pourplating on Saboraud Dextrose Agar and prepared according to manufacturer's instruction. The plates were incubated at $37^{\circ} \mathrm{C}$ for $48 \mathrm{~h}$. Series of sub-culturing was done until pure cultures were obtained and preserved on slant. 


\section{Identification of the amyloglucosidase producer strains}

Identification of the isolates was performed using morphological means and $16 \mathrm{~S}$ rDNA gene sequence analysis. The pure fungi strain were streaked on SDA agar and incubated overnight at $28^{\circ} \mathrm{C}$. A colony was observed under light microscope.

Genomic DNA extraction was carried out according to the protocol of Zymo Research Fungal DNA Mini Prep ${ }^{\mathrm{TM}}$ Instruction Manual and kit. A universal primers; forward primer F-ITS4: 5'TCCTCCGCTTATTGACATGS 3') and reverse primer R-ITS1: 5' TCCGTAGGTGAACCTGCGG 3') was used to amplify 16S rDNA gene (White et al., 1990). The PCR reaction for the amplification of the DNA extracts was performed for 36 cycles while the conditions used were initial denaturation at $96^{\circ} \mathrm{C}$ for 5 mins; denaturation at 94 ${ }^{\circ} \mathrm{C}$ for $30 \mathrm{~s}$; annealing at $56{ }^{\circ} \mathrm{C}$ for $30 \mathrm{~s}$; extension at $72{ }^{\circ} \mathrm{C}$ for $45 \mathrm{~s}$; final extension step at $72{ }^{\circ} \mathrm{C}$ for $7 \mathrm{mins}$; and final hold at $10^{\circ} \mathrm{C}$ indefinitely. Nucleotide sequences were determined by the analysis of fluorescently labeled ITS Region products generated by PCR cocktail mix on an AB 373a Strech (short gun) DNA Sequencer. (Applied Biosystems Genetic Analysis Systems, Thermo Fisher Scientific, Waltham, MA USA).Primer (ITS4: 5'TCCTCCGCTTATTGACATGS 3' and ITS1: 5' TCCGTAGGTGAACCTGCGG 3') were used in all sequencing reactions. The obtained sequences were aligned by submitting them to the non-reductant nucleotide database at Genbank using the BLAST search program in order to determine the identity of the isolate (http://www.ncbi.nlm.nch.gov). The Phylogenetic trees were constructed by using Neighbour-joining method of the MEGA 7 package (Kumar et al., 2016).

\section{Effect of Substrate composition on Amyloglucosidase Production}

Agricultural substrates (15 g) different composition samples were weighed into separate petri dishes (Table 1), moistened with $25 \mathrm{ml}$ distilled water. The whole content was homogenized using vortex mixer and sterilized at $121{ }^{\circ} \mathrm{C}$ for $30 \mathrm{~min}$. The fermentation process was initiated by inoculating evenly the medium with $2 \mathrm{ml}$ spore suspension of $A$. niger OTF and A. flavus CLOR1 appropriately. The media were then incubated at $37^{\circ} \mathrm{C}$ for $120 \mathrm{~h}$ in a static condition

\section{Enzyme Extraction}

Fermented substrate composition $(0.5 \mathrm{~g})$ was added to $15 \mathrm{ml}$ acetate buffer solution ( $\mathrm{pH} 5$ ) agitated and mixed thoroughly. The suspension was filtered out and then centrifuged at $4000 \mathrm{rpm}$ (Gupta et al., 2008). This solid-free supernatant was used as crude enzyme source for assaying amyloglucosidase activity.

\section{Enzyme Assay}

Amyloglucosidase activity was determined by adding $5 \mathrm{ml} 0.1 \%$ soluble starch; $1 \mathrm{ml} 0.1 \mathrm{M}$ acetate buffer at $\mathrm{pH} 5$, and $1 \mathrm{ml}$ crude enzyme solution together, thoroughly mixed and incubated at $40{ }^{\circ} \mathrm{C}$ in water bath for $10 \mathrm{~min}$. The reaction was stopped by the addition $0.5 \mathrm{ml}$ dinitrosalicylic acid reagent and heated for $5 \mathrm{~min}$. Absorbance was recorded at $540 \mathrm{~nm}$ (Gupta et al. 2008). The enzyme was assayed and amyloglucosidase activity was recorded and calculated as follows:

Amyloglucosidase Activity $=\Delta \mathrm{E} * \mathrm{Vf} * \mathrm{Vs}$

$$
\Delta \mathrm{t} * € * \mathrm{gds} * \mathrm{~d} \ldots \ldots \ldots \ldots . . . \text { Equation } 1
$$

Where

$\Delta \mathrm{E}=$ Absorbance at $540 \mathrm{~nm}$

$\mathrm{Vf}=$ Final volume including DNS

Vs $=$ Volume $(\mathrm{ml})$ of amyloglucosidase used

$\Delta \mathrm{t}=$ Time of hydrolysis

$€=$ Extinction coefficient

gds $=$ Dry weight of the substrate $(\mathrm{g})$

$\mathrm{d}=$ Diameter of curvette

One unit of amyloglucosidase activity is defined as the amount of enzyme that releases 1 umol of reducing sugar, per minute with glucose as its standard.

\section{Characterizations of Amyloglucosidase}

The crude amyloglucosidase was subjected to characterization by studying the following effect of $\mathrm{pH}$, temperature and storage stability

\section{Effect of pH}

The effect of $\mathrm{pH}$ was observed by using different buffers of varying $\mathrm{pH}$, citrate buffer of 3.5, acetate buffer of 4.5 and 5.5, and also phosphate buffer of 6.0, 6.5 and 7.0. The buffers were used to assay the enzyme following the enzyme extraction and assay procedures as described in Section 2.2.5 and 2.2.6 above respectively. The absorbance was recorded using wavelength of $540 \mathrm{~nm}$ and the activities of the enzymes were calculated using Eqn. 1.

\section{Effect of Temperature}

The composite substrate samples were subjected to various temperatures 30,35 and $40^{\circ} \mathrm{C}$ and incubated for $48 \mathrm{~h}$ and then enzyme was assayed using acetate buffer $\mathrm{pH} 5$ following the enzyme extraction and assay procedures as described in Section 2.2.5 and 2.2.6 above respectively. The activities of the enzymes were calculated using Equation 1.

\section{Effect of Storage Stability on Amyloglucosidase}

The composite substrate samples were prepared and incubated for $48 \mathrm{~h}$ at temperature $35{ }^{\circ} \mathrm{C}$. The fermented substrates were oven dried at $40{ }^{\circ} \mathrm{C}$ and portions were kept at $28{ }^{\circ} \mathrm{C}$ and $4{ }^{\circ} \mathrm{C}$ to monitor the storage stability on weekly basis. pH buffers 5 was used to assay the enzyme following the enzyme extraction and assay procedures as described in Section 2.2.5 and 2.2.6 above respectively. The absorbance was recorded using wavelength of $540 \mathrm{~nm}$. The activities of the enzymes were calculated using Eqn. 1.

\section{RESULTS AND DISCUSSION}

\section{Identification of Amyloglucosidase producing fungi}

The isolates were identified based on their morphology and confirmed by molecular characterization as Aspergillus niger OTF and A. flavusCLOR1. The phylogenic trees shown in Fig. 1 and 2 of Aspergillus niger OTF and A. flavus CLOR1 respectively revealed their relationship with closely related species. The two fungal sp. previously obtained from an orchard garden in McPherson University were selected for amyloglucosidase producers on agar plates, they both tested positive for the enzyme and were classified as excellent producer. Other isolates have been extensively studied and this correlated with amyloglucosidase produced by these fungi (Pandey, 1995; Pavezzi et al., 2008; Kumar et al., 2013). Inspite of present successes, the task of finding new highly active amyloglucosidase producer remains topical.

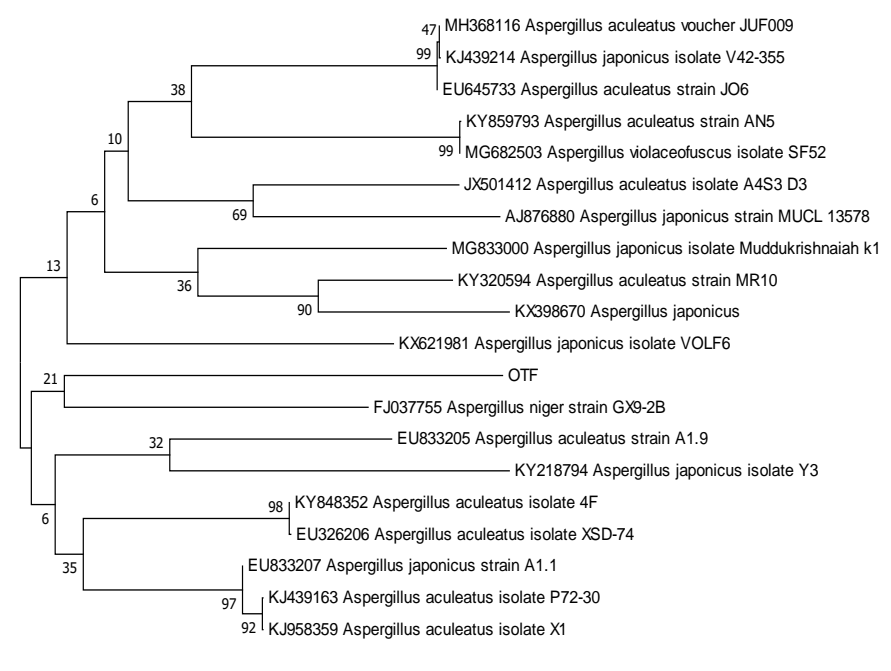
0.50

Figure 1 Phylogenetic tree based on gene shows the phylogenic relationship of strain OTF and indicates that it belongs to Aspergillus niger. FJ037755 Aspergillus niger strain GX9-2B is used as an in group 


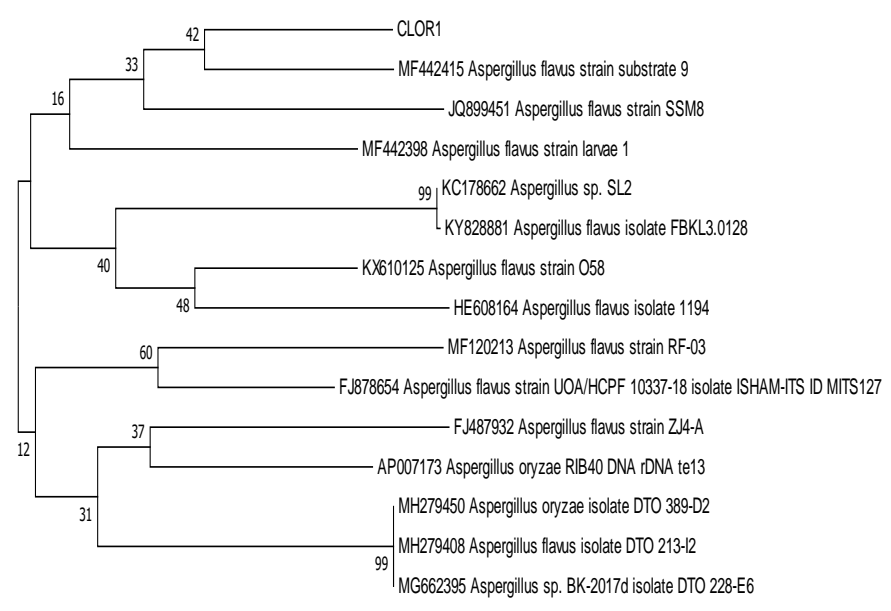

0.50

Figure 2 Phylogenetic tree based on gene shows the phylogenic relationship of strain CLOR1 and indicates that it belongs to Aspergillus flavus. MF442415 Aspergillus flavus strain substrate 9 is used as an in group.

Effect of Substrate composition and fermentation time on Amyloglucosidase production

The effect of substrate composition of agro-residues and fermentation time on amyloglucosidase activities by A. niger OTF and A. flavus CLOR1 respectively were presented in Fig. 3 (a) and (b). In Fig. 3 (a), Medium I (WSPO; 100:2:3:1, $\mathrm{w} / \mathrm{w}$ ) composting of the largest percentage of wheat bran (carbon source) with oyster shell as source of mineral yielded glucoamylase activity $83.92 \mathrm{Ug}^{-1}$ and next was medium V (WSP; 100:2:3, w/w) (67.64 $\mathrm{Ug}^{-1}$ ) composing same quantity of wheat bran but without oyster shell at optimal fermentation time of $48 \mathrm{~h}$. Medium VI with the highest wheat bran (carbon source) without the mineral source recorded the least activity $27 \mathrm{Ug}^{-1}$ at $48 \mathrm{~h}$. Generally, there was decline in activity of the enzyme after $48 \mathrm{~h}$ in all samples.

Fig. 3 (b) show that medium $\mathrm{V}$ also composting of the largest percentage of wheat bran with oyster shell as source of mineral yielded amyglucosidase activity $65.27 \mathrm{Ug}^{-1}$ and next was medium III at $60.1 \mathrm{Ug}^{-1}$ composing same quantity of wheat bran but without oyster shell at the optimal fermentation time. Medium VI recorded the least activity at $14.9 \mathrm{Ug}^{-1}$. Saccharomyces cerevisiae expressing glucoamylase from Aspergillus awamori yielded enzyme activity $0.09 \mathrm{Uml}^{-1}$ (Flory et al., 1994) while a recombinant Saccharomyces cerevisiae strains Stell7 produced glucoamylase activity $1.5 \mathrm{Uml}^{-1}$ (Knox et al., 2004). Saccharomyces diastaticus CL-9in glucose and starch medium resulted into extracellular glucoamylase activity $1.06 \mathrm{Uml}^{-1}$ (Peres et al., 2006). This shows that enzymes from these agro-substrates were more economical as compared with starchy substrate reported by these reserachers. Considering the enzyme yields from the main carbon sources i.e. wheat bran and rice bran, wheat bran produced more enzyme in comparison with rice bran Wheat bran as the most promising substrate for amyloglucosidase production has been reported by several researchers (Kaur et al., 2003; Anto et al., 2006; Costa et al., 2007; Kumar et al., 2013). Production of very high levels of a hard starch-gel digesting amyloglucosidase under SSF using wheat bran, rice bran, and other components has been reported by Singh and Soni, (2001) However, the enzyme was seen to exhibit its highest activity at $48 \mathrm{~h}$ for the both substrates

Table 1 Experimented substrate composition of agricultural residues used for amyloglucosidase production by Aspergillus niger OTF and A. flavus CLOR 1

\begin{tabular}{|c|c|c|c|c|c|c|}
\hline \multicolumn{2}{|r|}{ Sample Code } & $\begin{array}{l}\text { Wheat } \\
\text { Bran }\end{array}$ & $\begin{array}{l}\text { Rice } \\
\text { Bran }\end{array}$ & $\begin{array}{l}\text { Soybean } \\
\text { Flour }\end{array}$ & $\begin{array}{l}\text { Palm Kernel } \\
\text { Cake }\end{array}$ & $\begin{array}{l}\text { Oyst } \\
\text { Shel }\end{array}$ \\
\hline I & $\begin{array}{c}\text { WSPO } \\
(100: 20: 30: 1 \% \mathrm{w} / \mathrm{w})\end{array}$ & 10 & - & 2 & 3 & 0.1 \\
\hline II & $\begin{array}{c}\text { RSPO } \\
(100: 30: 20: 1 \% \mathrm{w} / \mathrm{w})\end{array}$ & - & 10 & 3 & 2 & 0.1 \\
\hline III & $\begin{array}{c}\text { WRSPO }_{1} \\
(50: 50: 20: 30: 1 \% \text { w/w) }\end{array}$ & 5 & 5 & 2 & 3 & 0.1 \\
\hline IV & $\begin{array}{c}\mathrm{WRSPO}_{2} \\
(50: 50: 30: 20: 1 \% \mathrm{w} / \mathrm{w})\end{array}$ & 5 & 5 & 3 & 2 & 0.1 \\
\hline V & $\begin{array}{c}\text { WSP } \\
(10: 2: 3 \% \mathrm{w} / \mathrm{w})\end{array}$ & 10 & - & 2 & 3 & - \\
\hline VI & $\begin{array}{c}\text { RSP } \\
(10: 3: 2 \% \text { w/w })\end{array}$ & - & 10 & 3 & 2 & - \\
\hline VII & $\begin{array}{c}\text { WRSPP }_{1} \\
(5: 5: 2: 3 \% \mathrm{w} / \mathrm{w})\end{array}$ & 5 & 5 & 2 & 3 & - \\
\hline VIII & $\begin{array}{c}\text { WRSP }_{2} \\
(5: 5: 3: 2 \% \mathrm{w} / \mathrm{w}) \\
\end{array}$ & 5 & 5 & 3 & 2 & - \\
\hline
\end{tabular}

Legend: W- Wheat bran; R- Rice bran; S- Soybean flour; P- Palm kernel cake; O- Oyster shell 


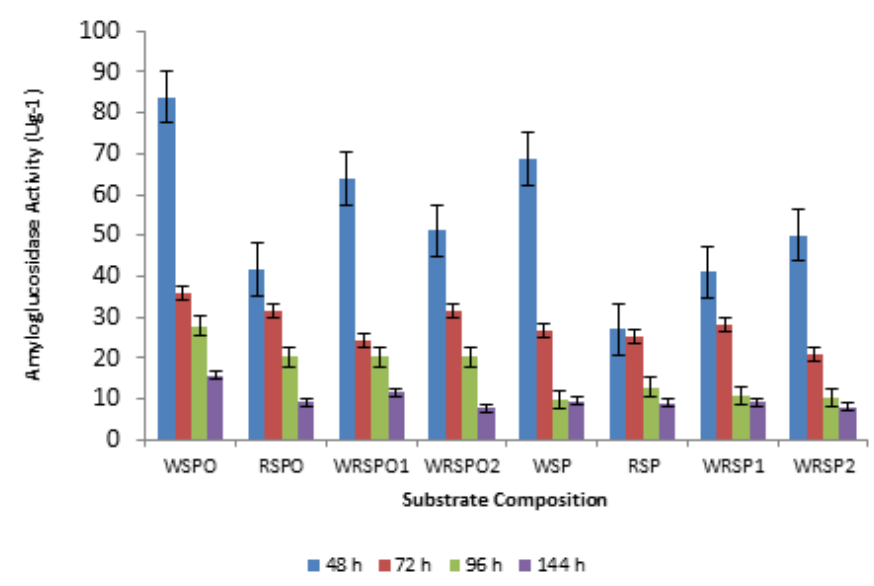

(a)

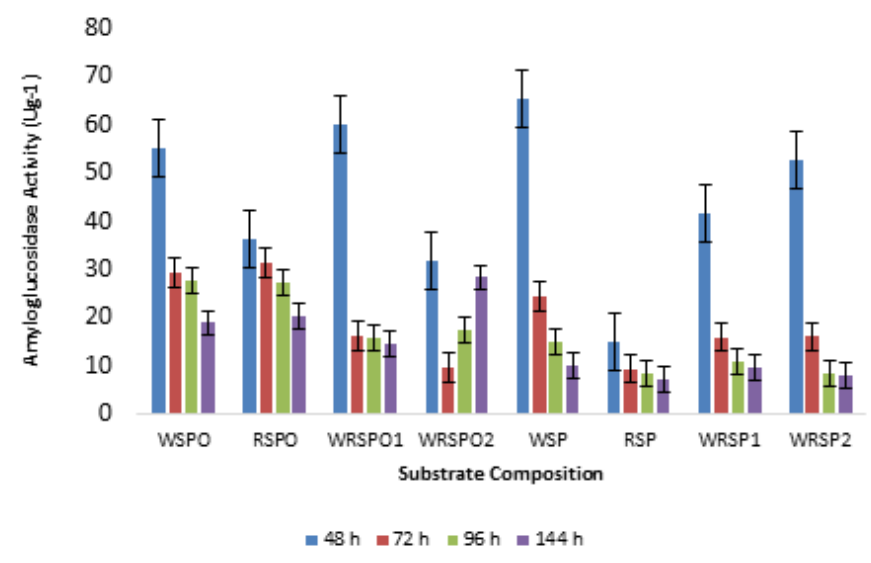

(b)

Figure 3 Effect of substrate composition on amyloglucosidase production by (a) Aspergillus niger OTF and (b) A. flavus CLOR1 (Error bars with standard error)

\section{Effect of pH on amyloglucosidase production}

A. niger OTF and A. flavus CLOR1 inoculated into different substrates were incubated at $30{ }^{\circ} \mathrm{C}$ for five days. The enzyme was extracted and the activities of amyloglucosidase produced at different $\mathrm{pH}$ were recorded (Fig. 4). The maximum amyloglucosidase activity was obtained at $\mathrm{pH} 5.0$ after $48 \mathrm{~h}$ of incubation at $37^{\circ} \mathrm{C}$. This was very high when compared to other $\mathrm{pH}$ range. Optimum $\mathrm{pH}$ is very important, the composition of cell wall and plasma membrane of microorganism is known to be affected by the culture $\mathrm{pH}$ Optimization of the culture conditions for amyloglucosidase production by Aspergillus $s p$ under SSF and optimum enzyme yield noted at $\mathrm{pH}$ 5. It has been reported that fungal amyloglucosidaseacts well in acidic medium (Norouzian $\boldsymbol{e}$ al., 2006). Optimum $\mathrm{pH}$ for amyloglucosidase from Aspergillus niger was 4.8 (Jafari-Aghdam et al., 2005) and amyloglucosidase from commercial preparations of Aspergillus niger gaveoptimum $\mathrm{pH}$ range of 3.5 - 5.0 (Ono et al., 1998).Vihinen and Mantsala (1989) also revealed that enzyme produced by Aspergillus sp. N-2 exhibited optimum $\mathrm{pH}$ in the range of $3.5-4.5$.

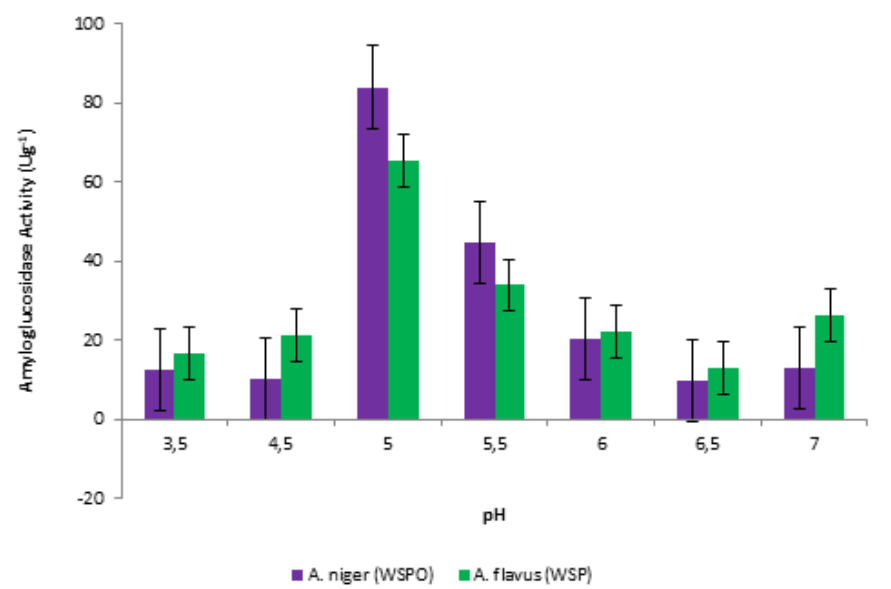

Figure 4 Effect of $\mathrm{pH}$ on amyloglucosidase production by $A$. niger OTF and $A$. flavus CLOR1 using WSPO and WSP substrates respectively (Error bars with standard error)

\section{Effect of Temperature on Amyloglucosidase production}

Growth temperature is a very critical parameter which varies from organism to organism and slight changes in growth temperature may affect amyloglucosidase production.Aspergillus niger OTF and A. flavus CLOR1 when incubated at different temperature 30,35 and $40{ }^{\circ} \mathrm{C}$, showed optimal yield of amyloglucosidase activity $82.8 \mathrm{Ug}^{-1}$ and $64.76 \mathrm{Ug}^{-1}$ at $30{ }^{\circ} \mathrm{C}$ respectively as shown in Fig. 5. This was contrary to other reports. Hata et al., (1997) reported that amyloglucosidase produced from Aspergillus oryzae cultivated in solid state fermentation resulted in optimum temperature $56{ }^{\circ} \mathrm{C}$. Another author described amyloglucosidase from Aspergillus sp. HA-2 that recorded optimum temperature $55^{\circ} \mathrm{C}$ (Anto et al., 2006).

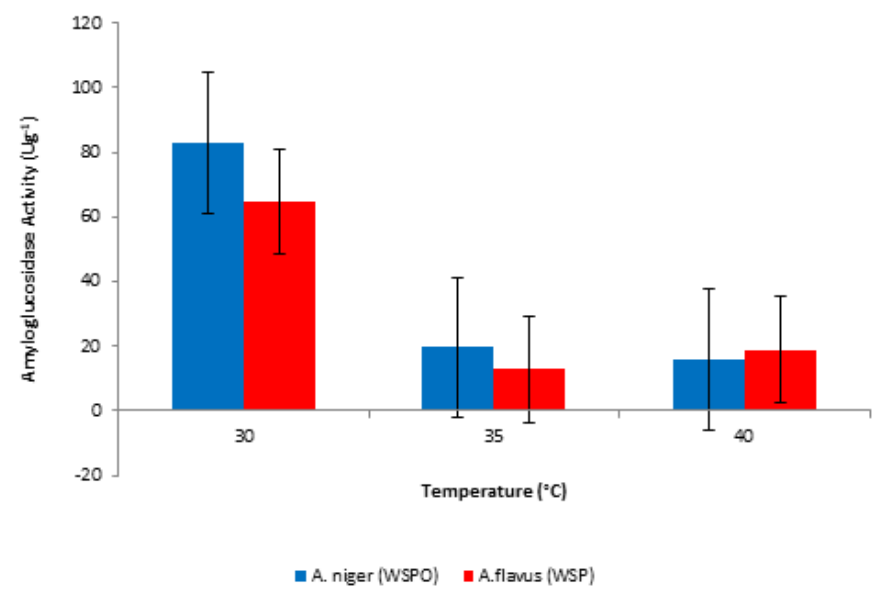

Figure 5 Effect of temperature on amyloglucosidase production by A. niger OTF A. flavus CLOR1using WSPO and WSP substrates respectively (Error bar with Standard errors)

\section{Effect of Storage Stability on amyloglucosidase production}

Cost- and time-effective production of amyloglucosidase was achieved by utilizing dried wheat brans powder as the substrate for production. The effect of storage stability on amyloglucosidase production by A. niger OTF and A. flavus CLOR 1 at $4{ }^{\circ} \mathrm{C}$ and $28{ }^{\circ} \mathrm{C}$ were presented in Fig. 6. The residual activities of $A$ niger OTF and A. flavus CLOR1were $43.9 \%$ and $44.9 \%$ at $4{ }^{\circ} \mathrm{C}$ and $68.6 \%$ and $27.8 \%$ at $28{ }^{\circ} \mathrm{C}$ in week 2 respectively. However, the activities at both storage conditions declined on weekly basis over a period of five weeks. Akpan and Adelaja (2004) reported on stabilization of enzyme preparation that stability is a function of storage time and substrate concentration and also there is a strong interaction between stabilizer concentration and storage time. The results also agreed with observations made by Tombs (1985), that enzyme stability is imparted by enzyme substrate. Its high stability ensures efficient utilization under industrial conditions. This work provides a very good platform for the enzyme immobilization studies and scale up production in future. 


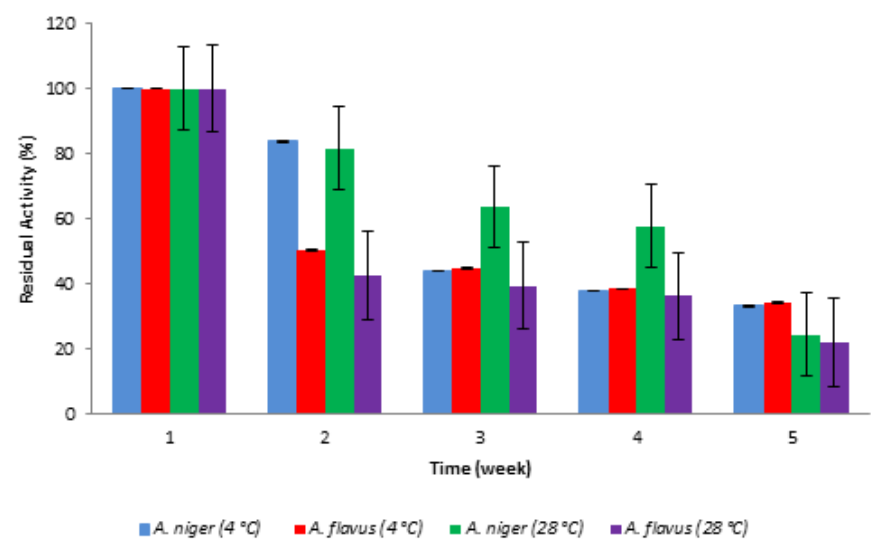

Figure 6 Effect of storage stability on amyloglucosidase production of $A$. niger OTF and A. flavus CLOR 1 at $4{ }^{\circ} \mathrm{C}$ and $28^{\circ} \mathrm{C}$ respectively

\section{CONCLUSION}

It has been demonstrated that $A$. niger OTF and A. flavus CLOR 1 has the potential to utilize agricultural waste residues for production of amyloglucosidase enzyme. The higher amyloglucosidase activity can be obtained on inexpensive and easily available substrate wheat bran by A. niger OTF in SSF. Thus wheat bran residue could be a potential, economic source for the production of amyloglucosidase by solid state fermentation. However, the characteristics of the enzyme provide platform for the enhancement of its industrial applications.

Acknowledgement: The authors thank the Technical Staff of Bioscience Laboratory, International Institute of Tropical Agriculture (IITA), Ibadan, Nigeria for the $16 \mathrm{~S}$ rDNA gene sequence analysis.

\section{REFERENCES}

Akpan, I. and Adelaja, F.A. (2004). Stabilization and production of amylase from rice bran solid medium. World Journal of Microbiology and Biotechnology 20: 47-50. http://dx.doi.10.1023/B:WIBI.0000013294.14446.cf

Aliyah,A. N., Edelweiss, E.M. , Sahlan, M., Wijanarko, A. and Hermansyah, H. (2016). Solid state fermentation using agro-industrial wastes to produce Aspergillus niger lipase as a biocatalyst immobilized by an adsorption crosslinking method for biodiesel synthesis. International Journal of Technology 7.8: 1392-1403 http://doi.org/10.14716/ijtech.v7i8.6988

Aliyah, A., Alamsyah, G., Ramadhani, R. and Hermansyah, H. (2017). Production of $\alpha$-Amylase and $\beta$-Glucosidase from Aspergillus niger by solid state fermentation method on biomass waste substrates from rice husk, bagasse and $\begin{array}{lllll}\text { corn cob. Energy } & \text { Procedia } & 136 & 418-423\end{array}$ http://dx.doi.org/10.1016/j.egypro.2017.10.269

Anto, H., Trivedi, U.B. and Patel, K.C. (2006). Glucoamylase production by solid-state fermentation using rice flake manufacturing waste products as substrate. Biological Resources Technology 97: 1161-1166. http://dx.doi.org/10.1016/j.biotech.2005.05.007

Costa, J. A. V., Colla,.E., Magagnin, G., dos Santos, L. O. Vendruscolo, M. and Bertolin, T.E. (2007). Simultaneous amyloglucosidase and exo-polygalacturonase production by Aspergillus niger using solid-state fermentation. Brazilian $\begin{array}{llll}\text { Archives of Biology and Technology (5):759 } & \end{array}$ 766.http://dx.doi.org/10.1590/S1516-89132007000500003

Finore, I., Donato, P.D., Poli, A., Kirdar, B., Kasavi, C., Toksoy, E. O., Nicolaus, B. and Lama, L. (2014). Use of agro waste biomass for $\alpha$-Amylase production by Anoxybacillus amylolyticus: Purification and properties. Journal of Microbial $\begin{array}{llll}\text { and Biochemical } & \text { Technology } & 320-326\end{array}$ http://dx.doi.org/10.4172/19485948.1000162

Flory, N.; Gorman, M.; Coutinho, P.M.; Ford, C. and Reilly, P.J. (1994) Thermosensitive mutants of Aspergillus awamori glucoamylase by random mutagenesis: inactivation kinetics and structural interpretation. Protein Engineering 7: 1005-1012.

Gupta, A., Gupta, V. K., Modi, D.R. and Y'Adava, L.P. (2008). Production and characterization of $\alpha$-amylase from Aspergillus niger. Biotechnology 7: 551-556. http://dx.doi.org/10.3923/biotech.2008.551.556

Hata, Y.; Ishida, H.; Kojima, Y.; Ichikawa, E.; Kawato, A.; Suginami, K. and Imayasu, S. (1997). Comparison of two glucoamylases produced by Aspergillus oryzae in solid-state culture (Koji) and submerged culture. Journal of Fermentation and Bioengineering 84: 532-537 http://dx.doi.org/10.1016/S0922-338X(97)81907-1

Jafari-Aghdam, J.; Khajek, K.; Ranjbar, B. and Nemat-Gorgani, M. (2005) Deglycosylation of glucoamylase from Aspergillus niger: Effects on structure, activity and stability. Biochemical and Biophysical Acta 1750: 61-68. http://dx.doi.org/10.1016/j.bbapap.2005.03.011
James, J. A. and Lee, B. H. (1996). Characterization of glucoamylase from Lactobacillus amylovorus ATCC 33621. Biotechnology Letters 18(12): 14011406 http://dx.doi.org/10.1007/BF00129343

Kaur, P., Grewal, H.S. and Kocher, G.S. (2003). Production of $\alpha$-amylase by Aspergillus niger using wheat bran in submerged and solid state fermentations. Indian Journal of Microbiology 43:143-145

Khan, J. A and Sachin K Y. (2011). Production of apha amylase Aspergillus niger Using cheaper substrates employing solid state fermentation. International Journal of Plant, Animal and Environment Science 5: 100-108.

Knox, A.M.; Du Preez, J.C. and Kilian, S.G. (2004). Starch fermentation characteristic of Saccharomyces cerevisiae strains transformed with amylase genes from Lipomyces kononenkoae and Saccharomyces fibuligera. Enzyme Microbial Technology 34: $453-$ 460.http://dx.doi.org/10.1016/j.enzmictec.2003.12.010

Kumar, M. S. Chandana, L and Sridevi. V. (2013). Production and optimization of glucoamylase from wheat bran by Aspergillus oryzae NCIM 1212 under solid state fermentation. International Journal of Application or Innovation in Engineering \& Management 2: 318-323.

Kumar S., Stecher G., and Tamura K. (2016). MEGA7: Molecular Evolutionary Genetics Analysis version 7.0 for bigger datasets. Molecular Biology and Evolution 33:1870-1874. http://dx.doi.org/10.1093/molbev/msw054

Lakshmi M.V.V.C. and Jyothi, P. (2014). Production and optimization of glucoamylase from Aspergillus oryzae NCIM 1212 using wheat bran, varying chemical parameters under solid state Fermentation. International Journal of Current Microbiology and Applied Science 3(5): 70-76

Norouzian, D.; Akbarzadeh, A.; Scharer, J.M. and Young, M.M. (2006). Fungal glucoamylases. Biotechnology Advanced 24(1):80 85.http://dx.doi.org/10.1016/j.biotechadv.2005.06.003

Ono, K.; ShintanI, K. and Shikata, S. (1988). Comparative studies of various molecular species in Aspergillus niger glucoamylase. Agricultural, Biologica and Chemical 52: 1699-16709. http://dx.doi.10.1080/00021369.1988.10868916

Pandey, A. (1995). Glucoamylase research: an overview. Starch/Starke 42: 439 445. http://dx.doi.org/10.1002/star.19950471108

Pavezzi, F. C., Gomes, E. and da Silva, R. (2008). Production and characterization of glucoamylase from fungus Aspergillus awamori expressed in yeast Saccharomyces cerevisiae using different carbon sources. Brazilian Journal of Microbiology

http://dx.doi.org/10.1590/S1517838220080001000024

39:108-114

Peres, M.F.S.; Souza, C.S.; Thomaz, D.; De Souza, A.R. and Laluce, C. (2006) Partitioning of the glucoamylase activity at the cell surfaces in culture of Saccharomyces. Process Biochemistry 41: 77-83

Singh H. and Soni, S. K. (2001). Production of starch-gel digesting amyloglucosidase by Aspergillus oryzae HS-3 in solid state fermentation Process Biochemistry 37(5):453-459. http://dx.doi.10.1016/S0032-9592(01)00238-2

Tombs, M.F. 1985. Review: Stability of enzymes. Journal of Applied Biochemistry 7:3-24

Vasudeo, Z. (2010). Solid state fermentation of Aspergillus oryzae for glucoamylase production on agro residues. International Journal of Life Science 4:16-25.http://dx.doi.org/10.3126/ijls.v4i0.2892

Vihinen, M and Mantsala, P. (1989). Microbial amylolytic enzymes. Critical Review Biochemical and Molecular Biology 24: 329-418 http://dx.doi.org/10.3109/10409238909082556

Wannapeera, J. and Suneerat P. (2008). Product yields and characteristics of rice husk, rice straw and corncob during fast pyrolysis in a drop-tube/fixed-bed reactor. Songklanakarin Journal of Science and Technology 30:393-404.

White, T. J, Bruns, T.D., Lee, S.B. and Taylor, J.W. (1990). Amplification and direct sequencing of fungal ribosomal RNA genes for phylogenetics. In: $P C R$ Protocols: a Guide to Methods and Applications (eds Innis MA, Gelfand DH Sninsky JJ, White TJ), pp.315.322. Academic Press, London, UK http://dx.doi.org/10.1016/B978-0-12-372180-8.50042-1 